https://doi.org/10.15407/ujpe65.4.317

V.YU. KUDRYA, ${ }^{1}$ V.M. YASHCHUK, ${ }^{1}$ A.P. NAUMENKO,${ }^{1}$ Y. MELY, ${ }^{2}$

YA.O. GUMENYUK ${ }^{3}$

1 Taras Shevchenko National University of Kyiv

(64/13, Volodymyrs'ka Str., Kyiv 01601, Ukraine; e-mail: vladkudrya@ukr.net)

2 Laboratoire de Biophotonique et Pharmacologie, Faculte de Pharmacie,

UMR 7213 CNRS, Universite de Strasbourg

(74 route du Rhin, 67401 Illkirch, France)

${ }^{3}$ National University of Life and Environmental Sciences of Ukraine

(15, Heroyiv Oborony Str., Kyiv 03041, Ukraine)

\title{
LOW-TEMPERATURE LUMINESCENT STUDIES OF EMISSIVE GUANINE SUBSTITUTE FOR THE DETECTION OF BIOPOLYMERS ${ }^{1}$
}

The optical absorption at $300 \mathrm{~K}$ and the fluorescence and phosphorescence at $78 \mathrm{~K}$ of the emissive guanine substitute, deoxythienoguanosine, $\left(d^{\text {th }} G\right)$ were investigated in aqueous and TRIS-HCl-buffer solutions. Two optical absorption and fluorescence centers at room temperature were attributed to two keto-enol tautomers of $d^{\text {th }} G$, which confirms previously obtained results. In contrast to room temperature, only one emission band was observed at $78 \mathrm{~K}$ in fluorescence spectra that was close to the long-wave fluorescence band at room temperature and could be associated with the tautomer with long-wave absorption. This phenomenon can be explained by the energy transfer by excitations in a frozen solution between two types of the optical centers mentioned above. The similar conclusion is drawn for the phosphorescence: only one tautomer phosphorescence band is observed. The spectral positions of this band maximum are essentially different for aqueous and buffer solutions ( $\sim 50 \mathrm{~nm})$.

Ke ywords: emissive guanine substitute, fluorescence, phosphorescence, energy transfer by excitations.

\section{Introduction}

The biopolymers of nucleic acids (DNA and RNA) are known pi-electron-containing macromolecules that are the main objects of the transfer, storage, and realization of the genetic information and, therefore, vitally important for any live creature. These biopolymers and their structural units - nucleotides manifest the autoluminescence with high quantum yield only at low temperatures that is well below the physiological range. At room temperature, the quantum yield of nucleotides is reported to be low, about $10^{-5}-10^{-4}$ [1]. The detection of nucleic acids becomes possible using luminescent probes ("modified" nucleosides, tautomerizable nucleoside analogs) with a respectable quantum yield of luminescence at room temperature which could be incorporated in the

(C) V.YU. KUDRYA, V.M. YASHCHUK,

A.P. NAUMENKO, Y. MELY,

YA.O. GUMENYUK, 2020

ISSN 2071-0194. Ukr. J. Phys. 2020. Vol. 65, No. 4 biopolymer macromolecule chain $[2,3]$. These probes would have distinct absorption and emission spectra and, due to their specific energy structure, could be additional traps of singlet and triplet excitations in the biopolymers of nucleic acids. Herein, the luminescent properties of such probe - deoxythienoguanosine $\left(\mathrm{d}^{\text {th }} \mathrm{G}\right)$ (Fig. 1), an isomorphic nucleoside analog acting as a faithful fluorescent substitute of guanine were studied at room and low temperatures.

\section{Experimental}

Deoxythienoguanosine $\left(\mathrm{d}^{\text {th }} \mathrm{G}\right)$ was obtained from Laboratoire de Biophotonique et Pharmacologie, Faculte de Pharmacie, Universite de Strasbourg, France. The solutions of $\mathrm{d}^{\text {th }} \mathrm{G}$ were prepared in distilled water and $50 \mathrm{mM}$ TRIS-HCl-buffer ( $\mathrm{pH} 7.2)$.

1 The paper was presented at XXIVth Galyna Puchkovska International School-Seminar "Spectroscopy of Molecules and Crystals" (August 25-30, 2019, Odesa, Ukraine). 
<smiles>[R]c1scc2c(=O)[nH]c(N)nc12</smiles>

Fig. 1. Chemical structure of deoxythienoguanosine $\left(\mathrm{d}^{\text {th }} \mathrm{G}\right)$

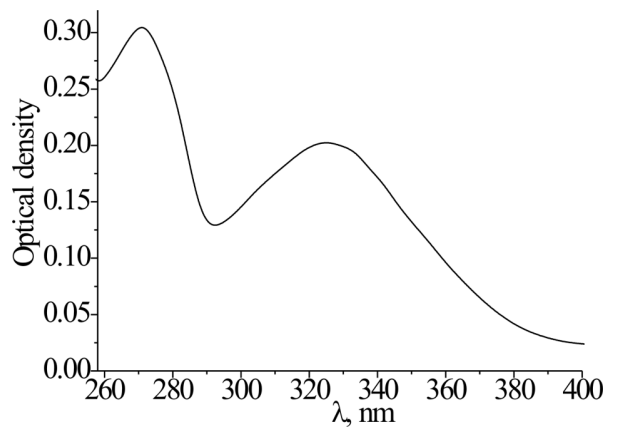

Fig. 2. Optical absorption spectrum of a $\mathrm{d}^{\text {th }} \mathrm{G}$ solution in TRIS-HCl-buffer

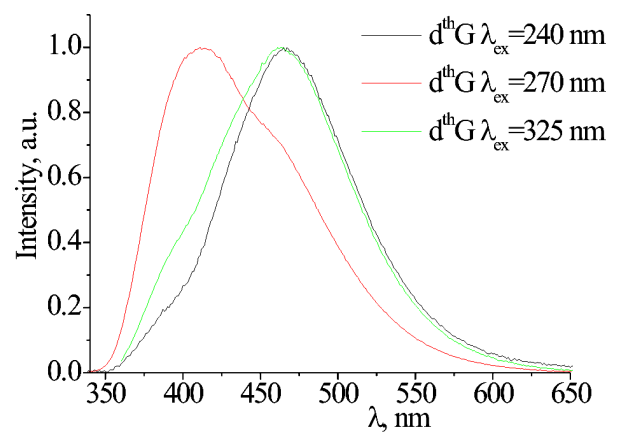

$a$

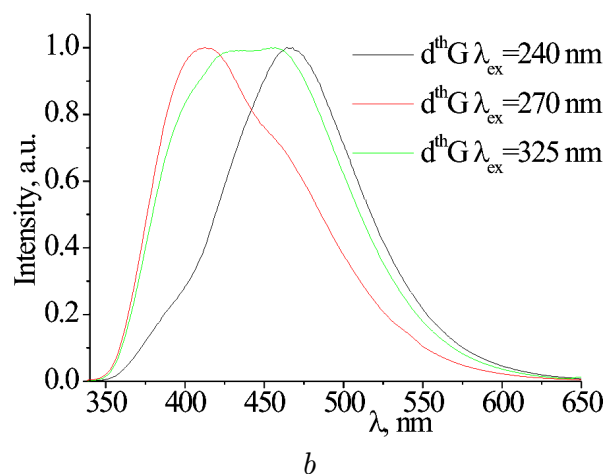

Fig. 3. Fluorescence spectra of a $\mathrm{d}^{\text {th }} \mathrm{G}$ solution in water $(a)$ and TRIS-HCl-buffer $(b)$ at different excitation wavelengths at a temperature of $300 \mathrm{~K}$
Concentrations were $C=2 \cdot 10^{-6} \mathrm{M}$. The optical absorption spectra of $\mathrm{d}^{\text {th }} \mathrm{G}$ solutions were recorded at $300 \mathrm{~K}$ using a Cary 60 UV-VIS spectrophotometer (Agilent Technologies Inc.) in standard quartz cuvettes. The fluorescence (at $300 \mathrm{~K}$ and $78 \mathrm{~K}$ ) and phosphorescence (at $78 \mathrm{~K}$ ) spectra were recorded using a fluorescent spectrophotometer Cary Eclipse (Varian, Australia). The experimental errors of wavelengths and intensities (optical densities) were standard for these equipments.

\section{Results and Discussion}

\subsection{Optical absorption} and fluorescence of $d^{\text {th }} G$ at $300 \mathrm{~K}$

Two ground-state keto-enol tautomers of $d^{\text {th }} \mathrm{G}$ early reported in [3] with shifted emission spectra that displayed distinct absorption and emission spectra were identified. The equilibrium between these two tautomers is mainly governed by the H-bond donor properties of the solvent. The present data obtained at room temperature $(300 \mathrm{~K})$ confirm the existence of two tautomers.

The optical absorption spectrum at room temperature of a $\mathrm{d}^{\text {th }} \mathrm{G}$ solution in buffer (Fig. 2) practically coincides with that reported in [3] and the optical absorption spectrum of the $\mathrm{d}^{\text {th }} \mathrm{G}$ solution in water. Most probably, the wide band with the maximum at $325 \mathrm{~nm}$ is a result of the addition of two bands associated with the optical absorption of two tautomers, respectively.

The fluorescence emission spectra at room temperature of $\mathrm{d}^{\text {th }} \mathrm{G}$ solutions in buffer and in water are complex and depend on the excitation wavelength. Excitations at shorter wavelengths $(240-260 \mathrm{~nm})$ give the emission spectrum (Fig. 3, black curve) centered at $468 \mathrm{~nm}$ that can be associated with one of two tautomers. Excitations at longer wavelengths (270$300 \mathrm{~nm}$ ) give the emission spectrum (Fig. 3, red curve) with two bands that can be associated with both tautomers, but the emission of another tautomer (with maximum at $410 \mathrm{~nm}$ ) becomes dominant. Excitations at $325 \mathrm{~nm}$ give different spectra (Fig. 3, green curve) for buffer and aqueous solutions. In buffer solutions, the emissions of both tautomers are equal in contrast to aqueous solutions. This fact could be explained by that the equilibrium between two tautomers, as was shown in [3], is governed by the $\mathrm{H}$ bond donor properties of the solvent. The redistri- 
bution of fluorescence emission intensities in aqueous solutions could be a result of the singlet excitation energy transfer (possibly, direct and reverse ones depending on $\mathrm{pH}$ ) between these two tautomers.

\subsection{The fluorescence of $d^{\text {th }} \mathrm{G}$ at $78 \mathrm{~K}$}

The spectra of fluorescence excitations at $78 \mathrm{~K}$ of $\mathrm{d}^{\text {th }} \mathrm{G}$ solutions in buffer are close to the optical absorption spectrum of $\mathrm{d}^{\text {th }} \mathrm{G}$ solutions at room temperature and practically coincide for the different emission wavelengths (Fig. 4, blue, rose, orange curves). The long-wave bands of these fluorescence excitation spectra possess two unsharp maxima at 315 and $334 \mathrm{~nm}$. This fact confirms the deconvolution of the absorption spectrum of $\mathrm{d}^{\text {th }} \mathrm{G}$ obtained in [3] in two ground-state tautomers even at a temperature of $78 \mathrm{~K}$. The same situation is for the aqueous solutions of $\mathrm{d}^{\text {th }} \mathrm{G}$.

In contrast to room temperature, only one emission band at $78 \mathrm{~K}$ was observed in the $\mathrm{d}^{\text {th }} \mathrm{G}$ fluorescence emission spectra that was close to the shortwave fluorescence band at room temperature (Fig. 4, black, red, green curves). This implies that the emission of one tautomer (with maximum at $410 \mathrm{~nm}$, as at room temperature) becomes dominant. The minor contribution of another tautomer (with maximum at $468 \mathrm{~nm}$, as at room temperature) to the mutual $\mathrm{flu}-$ orescence emission depends on the excitation wavelength (for the excitation wavelength $270 \mathrm{~nm}$, this contribution is the least). These data are partly in agreement with the data obtained at room temperature. The fact that the emission of one tautomer became dominant could be explained that the one-way excitation energy transfer to one of two tautomers took place substantially in contrast to the case of room temperature mentioned above. The same situation is for the aqueous solutions.

\subsection{Phosphorescence of $d^{\text {th }} G$ at $78 \mathrm{~K}$}

The phosphorescence emission spectra at a temperature of $78 \mathrm{~K}$ of $\mathrm{d}^{\text {th }} \mathrm{G}$ solutions in TRIS-HCl-buffer (Fig. 5, red, green, magenta curves) and in water (Fig. 5, blue, violet curves) are different and practically do not depend on the excitation wavelength. Obviously, there is the essential difference between the positions of phosphorescence maxima ( $\sim 50 \mathrm{~nm})$ of the aqueous and buffer solutions that cannot be attributed to experimental errors of equip-

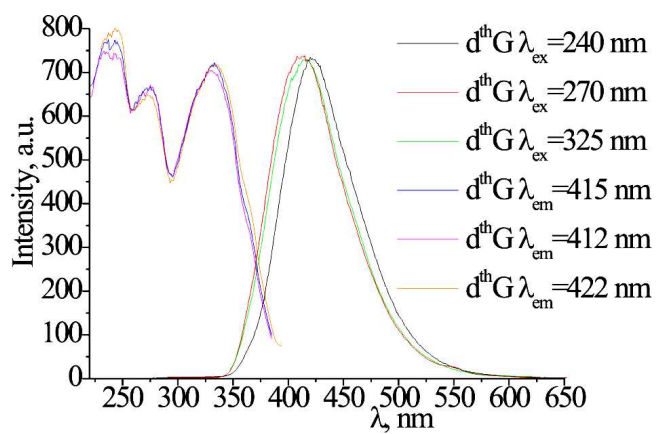

Fig. 4. Fluorescence excitation and emission spectra of a $d^{\text {th }} \mathrm{G}$ solution in TRIS-HCl-buffer at a temperature of $78 \mathrm{~K}$ for different emission and excitation wavelengths, respectively

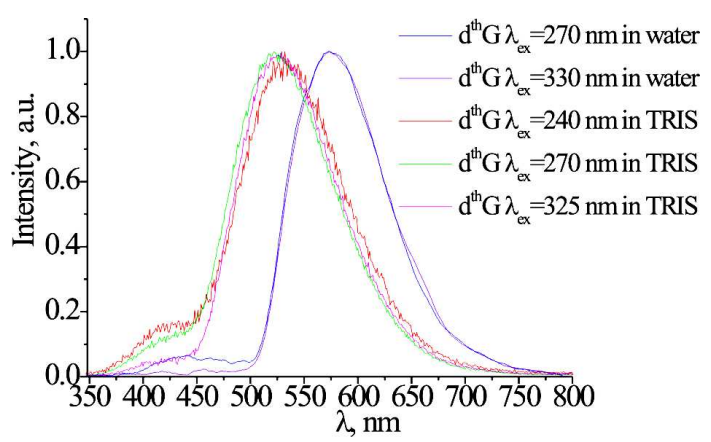

Fig. 5. Phosphorescence spectra of a $d^{\text {th }} \mathrm{G}$ solution in TRISHCl-buffer and water at a temperature of $78 \mathrm{~K}$ and different excitation wavelengths

ments. For the explanation of this phenomenon, two causes have to be taken into account. The first, as was mentioned above, is that the equilibrium between two tautomers is governed by the H-bond properties of the solvent [3]. The second one is as follows: the triplet states of organic compounds are sensitive to their photochemical or structure modifications $[4$, 5]. So, it is reasonable to suppose that the different tautomers emit different phosphorescence in the different solvents. The slight band in a short-wave interval $(350-450 \mathrm{~nm})$ is connected with residues of the fluorescence contribution.

\section{Conclusions}

1. In $\mathrm{d}^{\text {th }} \mathrm{G}$ solutions, two optical centers that can be associated with two ground-state keto-enol tautomers are manifested in the optical absorption and the fluorescence spectra at room temperature, as well as in the fluorescence excitation spectra at a temperature 
of $78 \mathrm{~K}$. The type of a solvent affects the position of fluorescent maxima.

2. At a temperature of $78 \mathrm{~K}$, the emission of one of these two tautomers of $\mathrm{d}^{\text {th }} \mathrm{G}$ dominates in fluorescence spectra. This fact can be explained by the one-way excitation energy transfer just to this tautomer.

3. Both tautomers of $\mathrm{d}^{\text {th }} \mathrm{G}$ are manifested in the phosphorescence spectra at a temperature of $78 \mathrm{~K}$ : the different tautomers emit different phosphorescence in the different solvents.

1. D. Onidas, D. Markovitsi, S. Marguet, A. Sharonov, T. Gustavsson. Fluorescence properties of DNA nucleosides and nucleotides: A refined steady-state and femtosecond investigation. J. Phys. Chem. B 106, 11367 (2002).

2. M. Sholokh, R. Sharma, D. Shin, R. Das, O.A. Zaporozhets, Y. Tor, Y. Mely. Conquering 2-aminopurine's deficiencies: Highly emissive isomorphic guanosine surrogate faithfully monitors guanosine conformation and dynamics in DNA. J. Am. Chem. Soc. 137, 3185 (2015).

3. M. Sholokh, R. Improta, M. Mori, R. Sharma, C. Kenfack, D Shin, K. Voltz, R.H. Stote, O.A. Zaporozhets, M. Botta, Y. Tor, Y. Mely. Tautomers of a fluorescent G surrogate and their distinct photophysics provide sensitive information channels. Angew. Chem. Int. Ed. 55, 7974 (2016).

4. M. Pope, C.E. Swenberg. Electronic Processes in Organic Crystals and Polymers (Oxford Univ. Press, 1999).
5. V.M. Yashchuk, V.Yu. Kudrya. The spectral properties of DNA and RNA macromolecules at low temperatures: Fundamental and applied aspects. Methods Appl. Fluoresc. 5, 014001 (2017).

Received 13.11.19

В.Ю. Кудря, В.М. Ящук,

А.П. Науменко, І. Мелі, Я.О. Гуменюк

ВИВЧЕННЯ ЛЮМІНЕСЦЕНЦІЇ

ЗАМІННИКА ГУАНІНУ ПРИ НИЗЬКИХ

ТЕМПЕРАТУРАХ ДЛЯ РЕЄСТРАЦЇ̈ БІОПОЛІМЕРІВ

$\mathrm{P}$ е $з$ ю м е

Досліджено оптичне поглинання (при $300 \mathrm{~K}$ ), флюоресценція та фосфоресценція (при $78 \mathrm{~K}$ ) випромінювального замінника гуаніну, деокситієногуанозину $\left(\mathrm{d}^{\text {th }} \mathrm{G}\right)$, у водному та ТРИC-HCl-буферному розчинах. Виявлено два центри оптичного поглинання та флюоресценції при кімнатній температурі, які віднесені до двох кето-енольних таутомерів, що підтверджує попередні результати. На відміну від кімнатної температури, при $78 \mathrm{~K}$ спостерігалась тільки одна смуга в спектрах флюоресценції, яка є схожою із довгохвильовою смугою флюоресценції при кімнатній температурі і асоціюється нами з таутомером, що має довгохвильове поглинання. Цей ефект можна пояснити існуванням передачі енергії збудження в замороженому розчині між згаданими оптичними центрами двох типів. Подібний висновок можна зробити і для фосфоресценції: спостерігається смуга лише одного таутомеру. Положення максимуму цієї смуги істотно різне для водного і буферного розчинів ( 50 нм). 